\title{
Pathogens of winter rapeseed cultivated in three production systems
}

\section{Patogeny rzepaku ozimego uprawianego w trzech technologiach produkcji}

\author{
Bożena Cwalina-Ambroziak ${ }^{1}$, Małgorzata Głosek ${ }^{1}$, Arkadiusz Stępień ${ }^{2}$
}

\section{Summary}

In a field experiment in Bałcyny winter rapeseed Brassica napus L. was grown in simplified crop rotation in three production systems: extensive, medium intensive and intensive. The rapeseed cultivars Californium, Castille and Nelson were grown in 2009 and 2012, and the cultivars Casoar, Artoga and Nelson were grown in 2011. During the growing season the severity of the following diseases sclerotinia rot (Sclerotinia sclerotiorum) and verticillium wilt (Verticillium spp.), grey mould (Botrytis cinerea), dark spot (Alternaria spp.) and dry rot (Phoma lingam) was evaluated twice. The aim of the study was to evaluate the severity of some diseases of winter rapeseed cultivated in three productions systems. With the increasing intensification of rapeseed production a decrease of disease severity was observed, especially in the last two years of carried out studies. Cultivars not explicitly differentiated the severity of sclerotinia rot and dark pod spot. Less severe symptoms of remaining diseases occurred on cultivar Nelson.

Key words: winter rapeseed; cultivar; production systems; pathogens

\section{Streszczenie}

W ścisłym doświadczeniu poletkowym w Bałcynach uprawiano rzepak ozimy (Brassica napus L.) w zmianowaniu uproszczonym z zastosowaniem trzech rodzajów technologii: oszczędnej, średnio intensywnej i intensywnej. W 2009 i 2012 roku uwzględniono odmiany Californium Castille i Nelson, a w 2011 roku: Casoar, Artoga i Nelson. W sezonie wegetacyjnym dwukrotnie oceniano nasilenie następujących chorób rzepaku: zgnilizny twardzikowej (Sclerotinia sclerotiorum), werticiliozy (Verticillium spp.), czerni krzyżowych (Alternaria spp.), szarej pleśni (Botryotinia fuckeliana st. kon. Botrytis cinerea) oraz suchej zgnilizny (Leptosphaeria biglobosa, L. maculans st. kon. Phoma lingam). Celem badań była ocena nasilenia wybranych chorób rzepaku ozimego uprawianego w trzech technologiach produkcji. Wraz ze wzrostem intensyfikacji technologii uprawy rzepaku zaobserwowano redukcję nasilenia objawów chorobowych na roślinach, co szczególnie uwidoczniło się w ostatnich dwóch latach badań. Odmiany niejednoznacznie różnicowały nasilenie zgnilizny twardzikowej i czerni krzyżowych na łuszczynach, a najsłabsze objawy pozostałych chorób stwierdzono na odmianie Nelson.

Słowa kluczowe: rzepak ozimy; odmiana; technologie produkcji; patogeny

\footnotetext{
Uniwersytet Warmińsko-Mazurski w Olsztynie

${ }^{1}$ Katedra Fitopatologii i Entomologii

Prawocheńskiego 17, 10-720 Olsztyn

bambr@uwm.edu.pl

${ }^{2}$ Katedra Systemów Rolniczych

pl. Łódzki 3, 10-727 Olsztyn

arkadiusz.stepien@uwm.edu.pl
} 


\section{Wstęp / Introduction}

Popularność uprawy rzepaku ozimego na świecie, w Europie i w Polsce wynika z możliwości jego wszechstronnego wykorzystania jako surowca w przemyśle spożywczym, farmaceutycznym, kosmetycznym, energetycznym oraz w produkcji mieszanek paszowych (Banaszkiewicz i Borkowska 2006). Wskazaniem do uprawy rzepaku jest m.in. wysoka wartość odżywcza nasion, tj. duża zawartość białka oraz tłuszczu, przy czym jakość pozyskiwanego oleju zależy od zawartości w nasionach kwasu oleinowego, linolowego i linolenowego (Wittkop i wsp. 2009).

W nowoczesnym, zrównoważonym rolnictwie uwzględnia się rosnące wymagania co do jakości płodów rolnych, jednocześnie biorąc pod uwagę jego związek z naturalnym środowiskiem. Osiągnięcie tych celów umożliwia stosowanie w uprawie roślin odpowiednich technologii produkcji z zamiarem m.in. zwiększenia ilości zużycia wody, ograniczenia użycia środków chemicznych (Kotecki i wsp. 2005). Szczególnie ważne jest stosowanie optymalnych zabiegów agrotechnicznych takich, jak nawożenie mineralne, w tym głównie azotem. Dawka i forma aplikacji składników pokarmowych powinny być zsynchronizowane $\mathrm{z}$ odmianą, warunkami temperaturowo-wilgotnościowymi gleby oraz stanowiskiem w zmianowaniu (Rathke i wsp. 2006). Siarka, która ma duże znaczenie w procesach fizjologicznych rośliny oraz enzymatycznych i oksyredukcyjnych na poziomie komórki, decyduje o efektywności wykorzystania zaaplikowanego nawożenia azotem. Stwierdzono zależność między nawożeniem azotem i siarką (Zhao i wsp. 2003; Wielebski 2006). Siarka determinuje również procesy naturalnej odporności na patogeny (Haneklaus i wsp. 2007). Rośliny należące do rodziny Brassicaceae (kapustowate) w warunkach stresu aktywują mechanizmy obronne m.in. przez zmiany akumulacji związków fenolowych, głównie kwasu synapinowego i synapiny (Jahangir i wsp. 2009). W uprawie rzepaku ozimego ważna jest ochrona przed agrofagami, w tym groźnymi organizmami grzybopodobnymi i grzyba- mi (Söchting i Verreet 2003; Jahangir i wsp. 2009; Jajor i wsp. 2012).

W badaniach podjęto próbę określenia wpływu zastosowania różnych technologii produkcji na zdrowotność wybranych odmian rzepaku ozimego uprawianego w zmianowaniu uproszczonym.

\section{Materiały i metody / Materials and methods}

Rzepak ozimy uprawiano w ścisłym doświadczeniu poletkowym w Zakładzie Produkcyjno-Doświadczalnym Sp. z o.o. w Bałcynach, w zmianowaniu uproszczonym: w 2009 r. - pierwszy rok trwania doświadczenia - przedplonem była mieszanka zbożowa jara (owies, jęczmień, pszenica jara) przeznaczona na zieloną paszę, bez nawożenia, w 2011 r. - po pszenicy ozimej i w 2012 r. po rzepaku ozimym. Czynnik doświadczenia stanowiły odmiany i technologie produkcji, obiekty doświadczenia wystąpiły w trzech powtórzeniach. W 2009 i 2012 r. uwzględniono dwie odmiany populacyjne: Californium i Castille oraz odmianę mieszańcową Nelson, a w 2011 r. odmianę populacyjną Casoar i mieszańcowe: Artoga i Nelson. Zastosowano trzy rodzaje technologii produkcji: oszczędną, średnio intensywną i intensywną, zróżnicowane pod względem nawożenia azotem i siarką, jak również ochrony przed agrofagami (tab. 1). W okresie wegetacji dwukrotnie szacowano zdrowotność roślin rzepaku: nasilenie zgnilizny twardzikowej (Sclerotinia sclerotiorum) i werticiliozy (Verticillium spp.) - \% chorych roślin na poletku, czerni krzyżowych (Alternaria spp.), szarej pleśni (Botryotinia fuckeliana st. kon. Botrytis cinerea) na liściach i łuszczynach oraz suchej zgnilizny (Leptosphaeria biglobosa, L. maculans st. kon. Phoma lingam) na łodygach - według 5-stopniowej skali, gdzie: 1 - poniżej 5\% porażonej powierzchni organów roślin, 5 - powyżej $50 \%$ porażonej powierzchni. Wyniki podano w postaci indeksu porażenia wyliczonego według wzoru Mc Kinneya (Łacicowa 1970), a następnie opracowano statystycznie (STATISTICA v. 10, w celu porównania średnich użyto testu Duncana, przyjmując poziom istotności 0,05).

Tabela 1. Zabiegi przeprowadzone w doświadczeniu w rzepaku ozimym

Table 1. Treatments carried in experiment in winter rapeseed

\begin{tabular}{|c|c|c|c|c|c|}
\hline \multirow{2}{*}{$\begin{array}{l}\text { Technologia } \\
\text { produkcji } \\
\text { Production } \\
\text { system }\end{array}$} & \multicolumn{2}{|c|}{$\begin{array}{l}\text { Nawożenie } \\
\text { Fertilization }\end{array}$} & \multicolumn{3}{|c|}{$\begin{array}{l}\text { Ochrona przed agrofagami } \\
\text { Protection against pests }\end{array}$} \\
\hline & $\begin{array}{l}\text { jesień } \\
\text { autumn }\end{array}$ & $\begin{array}{l}\text { wiosna } \\
\text { spring }\end{array}$ & $\begin{array}{l}\text { chwasty - weeds } \\
\text { jesień - autumn }\end{array}$ & $\begin{array}{l}\text { patogeny - pathogens } \\
\text { BBCH 50-59, 65-69 }\end{array}$ & $\begin{array}{l}\text { szkodniki (pąkowanie) } \\
\text { pests (budding) }\end{array}$ \\
\hline $\begin{array}{l}\text { Intensywna } \\
\text { Intensive }\end{array}$ & $\begin{array}{c}30 \mathrm{~kg} \mathrm{~N} \\
80 \mathrm{~kg} \mathrm{P} \\
150 \mathrm{~kg} \mathrm{~K}\end{array}$ & $\begin{array}{c}\mathrm{I}-120 \mathrm{~kg} \mathrm{~N} \\
\mathrm{II}-80 \mathrm{~kg} \mathrm{~N} \\
60 \mathrm{~kg} \mathrm{~S}\end{array}$ & $\begin{array}{c}\text { Butisan Star } 416 \text { SC } \\
\text { Perenal } 104 \text { EC }\end{array}$ & $\begin{array}{l}\text { Pictor } 400 \text { SC } \\
\text { Amistar } 250 \text { SC }\end{array}$ & $\begin{array}{l}\text { Nurelle D } 550 \text { EC } \\
\text { Decis 2,5 EC } \\
\text { Mospilan } 20 \text { SP }\end{array}$ \\
\hline $\begin{array}{l}\text { Średnio intensywna } \\
\text { Medium intensive }\end{array}$ & $\begin{array}{c}30 \mathrm{~kg} \mathrm{~N} \\
60 \mathrm{~kg} \mathrm{P} \\
120 \mathrm{~kg} \mathrm{~K} \\
\end{array}$ & $\begin{array}{c}\mathrm{I}-120 \mathrm{~kg} \mathrm{~N} \\
\mathrm{II}-60 \mathrm{~kg} \mathrm{~N} \\
45 \mathrm{~kg} \mathrm{~S}\end{array}$ & $\begin{array}{c}\text { Butisan Star } 416 \text { SC } \\
\text { Perenal } 104 \text { EC }\end{array}$ & $\begin{array}{c}\text { Alert } 375 \mathrm{SE} \\
\text { Horizon } 250 \mathrm{EW}\end{array}$ & $\begin{array}{l}\text { Nurelle D } 550 \text { EC } \\
\text { Mospilan } 20 \text { SP }\end{array}$ \\
\hline $\begin{array}{l}\text { Oszczędna } \\
\text { Economical }\end{array}$ & $\begin{array}{l}30 \mathrm{~kg} \mathrm{~N} \\
40 \mathrm{~kg} \mathrm{P} \\
60 \mathrm{~kg} \mathrm{~K}\end{array}$ & $\begin{array}{l}\mathrm{I}-120 \mathrm{~kg} \mathrm{~N} \\
\mathrm{II}-40 \mathrm{~kg} \mathrm{~N}\end{array}$ & Nimbus 283 SE & Pictor 400 SC & $\begin{array}{l}\text { Nurelle D } 550 \text { EC } \\
\text { Mospilan } 20 \text { SP }\end{array}$ \\
\hline
\end{tabular}




\section{Wyniki i dyskusja / Results and discussion}

Lata, w których prowadzono doświadczenie charakteryzowały się wysokimi opadami deszczu zwłaszcza $\mathrm{w}$ miesiącach letnich (tab. 2). Jednocześnie zanotowano umiarkowane temperatury powietrza, które $\mathrm{w}$ czerwcu 2011 r. i lipcu we wszystkich latach trwania doświadczenia przewyższały średnie miesięczne w tym samym okresie Z wielu lat (1961-2000). Sprzyjały one rozwojowi S. sclerotiorum, ponieważ ponad 20\% chorych roślin zanotowano w pierwszym roku badań we wszystkich rodzajach technologii $\mathrm{i}$ w drugim roku $\mathrm{w}$ technologii oszczędnej (tab. 3). W analizowanym okresie badań, tj. w 2009 i 2011 r. na podstawie interpretacji średnich dla technologii, najmniejsze porażenie roślin zanotowano $\mathrm{w}$ technologii intensywnej, a różnice między pozostałymi rodzajami technologii były istotne. Wpływ odmian na nasilenie choroby zaznaczył się w 2009 i 2011 r., a najzdrowsze okazały się odmiany populacyjne odpowiednio Californium i Casoar. Starzycka i Starzycki (1994) podają, że stosunkowo dużym problemem $\mathrm{w}$ walce ze sprawcą zgnilizny twardzikowej jest funkcjonowanie mechanizmów odpornościowych roślin, ponieważ młodsze tkanki ulegają znacznie wcześniej porażeniu niż starsze. Wójtowicz i Jajor (2010) informują o ograniczeniu nasilenia takich chorób, jak: zgnilizna twardzikowa, sucha zgnilizna kapustnych, szara pleśń i czerń krzyżowych (z jednoczesnym wzrostem plonu nasion) na rzepaku ozimym chronionym fungicydami jesienią oraz wiosną. Największy wzrost plonu nasion autorzy zanotowali na poletkach $\mathrm{z}$ trzykrotną aplikacją fungicydami.

Objawy porażenia przez sprawcę werticiliozy wystąpiły w mniejszym nasileniu niż przez sprawcę zgnilizny twardzikowej, z najwyższym 4 i 4,5\% porażeniem roślin odmiany Artoga w oszczędnej i średnio intensywnej technologii w 2011 r. (tab. 3). W ostatnich dwóch latach badań stwierdzono istotnie słabsze porażenie przez oceniane patogeny rzepaku w technologii intensywnej. Podczas całego cyklu trwania doświadczenia okazały się najzdrowszymi odmiana Nelson oraz odmiana Castille w pierwszym roku badań. $\mathrm{Z}$ doniesień literaturowych wynika, że uprawa $\mathrm{w}$ systemach uproszczonych lub $\mathrm{w}$ monokulturze przyczynia się do pogorszenia stanu zdrowotnego roślin (Korbas 2008; Kurowski i wsp. 2008). Jak podają Rimmer i wsp. (2007) podstawową metodą ograniczania występowania sprawców werticiliozy i kiły kapusty jest stosowanie racjonalnego płodozmianu.

Panujące warunki pogodowe $\mathrm{w}$ analizowanych sezonach wegetacyjnych sprzyjały rozwojowi czerni krzyżowych i szarej pleśni na liściach. Choroby wystąpiły w podobnym nasileniu podczas całego okresu badawczego, ale najbardziej nasiliły się w 2009 r., co było związane z wysoką sumą opadów w maju i czerwcu. W tym sezonie największe porażenie roślin przez Alternaria spp. (około $20 \%$ ) zanotowano na odmianie Californium w technologii oszczędnej (tab. 4), a najsilniejsze objawy porażenia przez B. cinerea (19-24\%) na odmianie Castille we wszystkich rodzajach technologii. $\mathrm{W}$ pozostałych latach nasilenie czerni krzyżowych i szarej pleśni nie przekraczało 15\% (wyjątek odmiana Casoar w technologii oszczędnej w 2011 r.), można tłumaczyć niższymi sumami opadów w analogicznym okresie. Najmniej porażone przez powyższych sprawców chorób okazały się rośliny intensywnie nawożone $\mathrm{z}$ optymalną ochroną oraz odmiana Nelson, na co wskazuje analiza średnich wartości indeksów porażenia odpowiednio dla technologii produkcji i odmiany. W badaniach przeprowadzonych przez Mączyńską i wsp. (2007) stwierdzono, że zastosowanie preparatu A 14049 zawierającego difenokonazol (fungicyd) i pachlobutrazol (inhibitor syntezy giberelin) ograniczało występowanie chorób liści rzepaku ozimego o 87-91\%. Jak podają Kowalska i Remlein-Starosta (2011) zastosowanie pojedynczej dawki preparatu biologicznego Trifender opartego na sporach grzyba Trichoderma asperellum, skutecznie

Tabela 2. Warunki pogodowe według Stacji Meteorologicznej w Bałcynach (2008-2012)

Table 2. Weather conditions (Meteorological Station in Bałcyny) (2008-2012)

\begin{tabular}{l|r|r|r|r|r|r|r|r|c|c}
\hline & \multicolumn{3}{|c|}{ Temperature - Temperature [ $\left.{ }^{\circ} \mathrm{C}\right]$} & \multicolumn{4}{c}{ Opady - Rainfall [mm] } \\
\hline $\begin{array}{l}\text { Miesiąc } \\
\text { Month }\end{array}$ & $\begin{array}{c}2008 / \\
2009\end{array}$ & $\begin{array}{c}2009 / \\
2010\end{array}$ & $\begin{array}{c}2010 / \\
2011\end{array}$ & $\begin{array}{c}2011 / \\
2012\end{array}$ & $\begin{array}{c}\text { średnia } \\
\text { mean } \\
1961- \\
2000\end{array}$ & $\begin{array}{c}2008 / \\
2009\end{array}$ & $\begin{array}{c}2009 / \\
2010\end{array}$ & $\begin{array}{c}2010 / \\
2011\end{array}$ & $\begin{array}{c}2011 / \\
2012\end{array}$ & $\begin{array}{c}\sum \\
1961- \\
2000\end{array}$ \\
\hline Sierpień - August & 17,7 & 18,5 & 19,3 & 18,1 & 18,2 & 103,1 & 25,7 & 99,3 & 83,6 & 78,1 \\
\hline Wrzesień - September & 11,9 & 14,7 & 12,2 & 14,6 & 12,6 & 17,0 & 15,6 & 45,0 & 38,9 & 57,1 \\
\hline Październik - October & 8,6 & 5,9 & 5,3 & 8,6 & 8,1 & 104,6 & 58,5 & 11,2 & 29,9 & 54,0 \\
\hline Listopad - November & 4,0 & 5,2 & 4,4 & 3,1 & 2,8 & 40,5 & 40,8 & 110,4 & 9,6 & 51,4 \\
\hline Grudzień - December & $-0,2$ & $-1,7$ & $-6,9$ & 2,4 & $-1,3$ & 29,4 & 29,6 & 39,2 & 46,0 & 40,4 \\
\hline Styczeń - January & $-3,7$ & $-8,9$ & $-1,6$ & $-2,0$ & $-3,5$ & 16,2 & 13,3 & 29,6 & 87,7 & 26,3 \\
\hline Luty - February & $-1,5$ & $-2,9$ & $-6,1$ & $-7,5$ & $-2,6$ & 14,7 & 14,2 & 20,5 & 24,9 & 19,6 \\
\hline Marzec - March & 1,9 & 2,1 & 2,0 & 3,5 & 1,2 & 68,0 & 23,8 & 8,6 & 21,3 & 27,4 \\
\hline Kwiecień - April & 9,7 & 7,9 & 9,7 & 8,4 & 6,6 & 3,7 & 9,4 & 33,7 & 44,7 & 35,2 \\
\hline Maj- May & 12,2 & 12,0 & 13,6 & 13,9 & 12,4 & 89,6 & 105,5 & 41,5 & 42,5 & 56,7 \\
\hline Czerwiec - June & 14,7 & 15,7 & 17,5 & 15,2 & 15,7 & 133,1 & 73,7 & 56,2 & 107,2 & 68,3 \\
\hline Lipiec - July & 18,9 & 20,8 & 18,0 & 19,0 & 15,3 & 82,2 & 87,8 & 171,9 & 11,2 & 81,3 \\
\hline
\end{tabular}


Tabela 3. Porażenie rzepaku ozimego przez patogeny - \% chorych roślin

Table 3. Infection of winter rapeseed by pathogens $-\%$ of infestated plants

\begin{tabular}{|c|c|c|c|c|c|c|c|c|c|}
\hline \multirow{2}{*}{$\begin{array}{l}\text { Rok } \\
\text { Year }\end{array}$} & \multirow{2}{*}{$\begin{array}{l}\text { Odmiana } \\
\text { Cultivar }\end{array}$} & \multicolumn{4}{|c|}{ Zgnilizna twardzikowa - S. sclerotiorum } & \multicolumn{4}{|c|}{ Werticillioza - Verticillium spp. } \\
\hline & & $\mathrm{O}^{*}$ & SI & I & $\mathrm{x}$ & $\mathrm{O}$ & SI & I & $\mathrm{x}$ \\
\hline \multirow{3}{*}{2009} & Californium & $23,5 \mathrm{abc}$ & $20,8 \mathrm{bc}$ & $20,2 \mathrm{c}$ & $21,5 \mathrm{~b}$ & $3,5 \mathrm{a}$ & $3,3 \mathrm{ab}$ & $3,1 \mathrm{ab}$ & $3,3 \mathrm{a}$ \\
\hline & Castille & $25,3 \mathrm{abc}$ & $27,4 \mathrm{a}$ & $24,4 \mathrm{abc}$ & $25,7 \mathrm{a}$ & $3,4 \mathrm{ab}$ & $0 \mathrm{e}$ & $1,7 \mathrm{~cd}$ & $1,7 \mathrm{~b}$ \\
\hline & Nelson & 28,6 a & $25,5 \mathrm{ab}$ & $20,3 \mathrm{c}$ & 24,8 a & $2,1 \mathrm{bcd}$ & $1,2 \mathrm{~d}$ & $2,7 \mathrm{abc}$ & $2,0 \mathrm{~b}$ \\
\hline \multicolumn{2}{|c|}{ Średnia-Mean } & $25,8 \mathrm{a}$ & $24,6 \mathrm{a}$ & $21,6 \mathrm{~b}$ & & $3,0 \mathrm{a}$ & $1,5 \mathrm{~b}$ & $2,5 \mathrm{a}$ & \\
\hline \multirow{3}{*}{2011} & Casoar & $15,3 \mathrm{c}$ & $12,1 \mathrm{cde}$ & 9,3 ef & $12,2 \mathrm{~b}$ & $3,9 \mathrm{ab}$ & $3,5 \mathrm{abc}$ & $3,0 \mathrm{bcd}$ & $3,5 \mathrm{a}$ \\
\hline & Artoga & $20,7 \mathrm{~b}$ & 10,0 def & 9,1 ef & $13,3 \mathrm{ab}$ & $4,5 \mathrm{a}$ & $4,0 \mathrm{ab}$ & $2,4 \mathrm{~cd}$ & $3,6 \mathrm{a}$ \\
\hline & Nelson & $25,2 \mathrm{a}$ & $13,3 \mathrm{~cd}$ & $6,5 \mathrm{f}$ & $15,0 \mathrm{a}$ & $2,4 \mathrm{~cd}$ & $3,0 \mathrm{bcd}$ & $1,8 \mathrm{~d}$ & $2,4 \mathrm{~b}$ \\
\hline \multicolumn{2}{|c|}{ Średnia - Mean } & $20,4 \mathrm{a}$ & $11,8 \mathrm{~b}$ & $8,3 \mathrm{c}$ & & $3,6 \mathrm{a}$ & $3,5 \mathrm{a}$ & $2,4 \mathrm{~b}$ & \\
\hline \multirow{3}{*}{2012} & Californium & $0,7 \mathrm{abc}$ & $0,8 \mathrm{abc}$ & $0,8 \mathrm{abc}$ & $0,8 \mathrm{a}$ & $2,7 \mathrm{~b}$ & $2,6 \mathrm{~b}$ & $2,2 \mathrm{c}$ & $2,5 \mathrm{a}$ \\
\hline & Castille & $0,7 \mathrm{abc}$ & $0,9 \mathrm{abc}$ & $0,9 \mathrm{abc}$ & $0,8 \mathrm{a}$ & $3,2 \mathrm{a}$ & $2,6 \mathrm{~b}$ & $2,4 \mathrm{bc}$ & $2,7 \mathrm{a}$ \\
\hline & Nelson & $0,5 \mathrm{c}$ & $0,7 \mathrm{abc}$ & $0,5 \mathrm{c}$ & $0,6 \mathrm{a}$ & $0,8 \mathrm{~d}$ & $0,5 \mathrm{de}$ & $0,4 \mathrm{e}$ & $0,6 \mathrm{~b}$ \\
\hline \multicolumn{2}{|c|}{ Średnia - Mean } & $0,6 \mathrm{~b}$ & $0,8 \mathrm{ab}$ & $0,8 \mathrm{ab}$ & & $2,1 \mathrm{~b}$ & $1,9 \mathrm{~b}$ & $1,6 \mathrm{c}$ & \\
\hline
\end{tabular}

*technologie - technologies: O - oszczędna - economical; SI - średnio intensywna - medium intensive; I - intensywna - intensive $\mathrm{x}$ - statystyka w obrębie lat - statistics for years

Wartości oznaczone w kolumnach tymi samymi literami nie różnią się istotnie - The values in columns marked with the same letters are not significantly different

Tabela 4. Porażenie liści rzepaku ozimego przez patogeny - indeks porażenia [Ip \%]

Table 4. Infection of leaves of winter rapeseed by pathogens - index of infection [Ii \%]

\begin{tabular}{|c|c|c|c|c|c|c|c|c|c|}
\hline \multirow{2}{*}{$\begin{array}{l}\text { Rok } \\
\text { Year }\end{array}$} & \multirow{2}{*}{$\begin{array}{l}\text { Odmiana } \\
\text { Cultivar }\end{array}$} & \multicolumn{4}{|c|}{ Czerń krzyżowych - Alternaria spp. } & \multicolumn{4}{|c|}{ Szara pleśń - B. cinerea } \\
\hline & & $\mathrm{O}^{*}$ & SI & I & $\mathrm{x}$ & $\mathrm{O}$ & SI & I & $\mathrm{x}$ \\
\hline \multirow{3}{*}{2009} & Californium & $19,2 \mathrm{a}$ & $16,8 \mathrm{ab}$ & $16,2 \mathrm{ab}$ & $17,4 \mathrm{a}$ & $17,3 \mathrm{bcd}$ & $15,2 \mathrm{bcd}$ & $13,4 \mathrm{~d}$ & $15,3 \mathrm{~b}$ \\
\hline & Castille & $16,7 \mathrm{ab}$ & $17,6 \mathrm{a}$ & $13,1 \mathrm{bc}$ & $15,8 \mathrm{a}$ & $23,9 \mathrm{a}$ & $19,8 \mathrm{ab}$ & $18,7 \mathrm{~b}$ & $20,8 \mathrm{a}$ \\
\hline & Nelson & $13,6 \mathrm{bc}$ & $13,0 \mathrm{bc}$ & $12,1 \mathrm{c}$ & $12,9 \mathrm{~b}$ & $18,2 \mathrm{bc}$ & $16,9 \mathrm{bcd}$ & $13,8 \mathrm{~cd}$ & $16,3 \mathrm{~b}$ \\
\hline \multicolumn{2}{|c|}{ Średnia - Mean } & $16,5 \mathrm{a}$ & $15,8 \mathrm{ab}$ & $13,8 \mathrm{~b}$ & & $19,8 \mathrm{a}$ & $17,3 \mathrm{~b}$ & $15,3 \mathrm{~b}$ & \\
\hline \multirow{3}{*}{2011} & Casoar & $16,8 \mathrm{a}$ & $14,7 \mathrm{ab}$ & $11,5 \mathrm{~b}$ & $14,7 \mathrm{a}$ & $18,3 \mathrm{a}$ & $11,8 \mathrm{~d}$ & $10,8 \mathrm{~cd}$ & $13,6 \mathrm{a}$ \\
\hline & Artoga & $12,4 \mathrm{~b}$ & $12,7 \mathrm{~b}$ & $5,2 \mathrm{c}$ & $10,1 \mathrm{~b}$ & $15,8 \mathrm{ab}$ & $13,4 \mathrm{bc}$ & $8,8 \mathrm{de}$ & $12,7 \mathrm{a}$ \\
\hline & Nelson & $6,9 \mathrm{c}$ & $8,1 \mathrm{c}$ & $5,5 \mathrm{c}$ & $6,8 \mathrm{c}$ & $8,8 \mathrm{de}$ & 7,2 ef & $5,3 \mathrm{f}$ & $7,1 \mathrm{~b}$ \\
\hline \multicolumn{2}{|c|}{ Średnia - Mean } & $11,7 \mathrm{a}$ & $12,5 \mathrm{a}$ & $7,4 \mathrm{~b}$ & & $14,3 \mathrm{a}$ & $10,8 \mathrm{~b}$ & $8,3 \mathrm{c}$ & \\
\hline \multirow{3}{*}{2012} & Californium & $10,0 \mathrm{ab}$ & $8,7 \mathrm{abc}$ & $6,0 \mathrm{bc}$ & $8,2 \mathrm{a}$ & $8,0 \mathrm{ab}$ & $8,7 \mathrm{a}$ & $7,3 \mathrm{ab}$ & $8,0 \mathrm{a}$ \\
\hline & Castille & $8,0 \mathrm{abc}$ & $10,0 \mathrm{ab}$ & $6,7 a b c$ & $8,2 \mathrm{a}$ & $7,3 \mathrm{ab}$ & $8,7 \mathrm{a}$ & $6,0 \mathrm{ab}$ & $7,3 \mathrm{ab}$ \\
\hline & Nelson & $7,3 \mathrm{abc}$ & $7,3 a b c$ & $4,7 \mathrm{c}$ & $6,4 \mathrm{~b}$ & $9,3 \mathrm{a}$ & $7,3 \mathrm{ab}$ & $3,3 \mathrm{~b}$ & $6,6 \mathrm{~b}$ \\
\hline \multicolumn{2}{|c|}{ Średnia - Mean } & $8,4 \mathrm{a}$ & $8,7 \mathrm{a}$ & $5,8 \mathrm{~b}$ & & $8,2 \mathrm{a}$ & $8,2 \mathrm{a}$ & $5,6 \mathrm{~b}$ & \\
\hline
\end{tabular}

*technologie - technologies: O - oszczędna - economical; SI - średnio intensywna - medium intensive; I - intensywna - intensive $\mathrm{x}$ - statystyka w obrębie lat - statistics for years

Wartości oznaczone w kolumnach tymi samymi literami nie różnią się istotnie - The values in columns marked with the same letters are not significantly different

ograniczało występowanie szarej pleśni na liściach rzepaku, natomiast podwojenie dawki środka Trifender spowodowało większe porażenie przez $B$. cinerea. Nie dowiedziono hamującego działania tego preparatu na występowanie czerni krzyżowych na liściach rzepaku ozimego.

Wysokie opady w czerwcu i lipcu, a zwłaszcza ich równomierny rozkład w 2012 r., sprzyjały rozwojowi czerni krzyżowych i szarej pleśni na łuszczynach rzepaku ozimego (tab. 5). Zanotowano wówczas największy indeks porażenia przez sprawców tych chorób w technologii oszczędnej, jednak różnice do analogicznych wartości w pozostałych rodzajach technologii nie zostały potwierdzone statystycznie. Istotne różnice w nasileniu chorób między obiektami uwzględniającymi technologie produkcji stwierdzono we wcześniejszych latach badań, dotyczy to jednak tylko porażenia łuszczyn przez Alternaria spp. (wyjątek porażenie przez $B$. cinerea odmiany Casoar w 2011 r.). Uzyskane średnie wartości dla odmiany pozwalają na stwierdzenie, że w analizowanym okresie badawczym wpływ uprawianych odmian na nasilenie czerni 
krzyżowych na łuszczynach był niejednoznaczny, natomiast istotnie słabsze objawy szarej pleśni wystąpiły na odmianie Nelson w uprawie rzepaku po pszenicy ozimej i po sobie. Według Jajor i wsp. (2012) wpływ na nasilenie powyższych chorób na łuszczynach miały warunki pogodowe, ochrona chemiczna i zmianowanie. Autorzy stwierdzili ograniczenie porażenia łuszczyn przez patogeny rzepaku uprawianego po jęczmieniu ozimym. Infekcja łuszczyn wskutek redukcji powierzchni asymilacyjnej była przyczyną spadku plonu ilościowego i jakościowego nasion wraz $\mathrm{z}$ ich nierównomiernym dojrzewaniem (Rimmer i wsp. 2007). Mączyńska i wsp. (2002) podkreślają pozytywny wpływ stosowanej ochrony na plon nasion, dowodzą efektywności fungicydów stosowanych na początku kwitnienia w ograniczaniu występowania czerni krzyżowych i szarej pleśni w warunkach wczesnej infekcji

Tabela 5. Porażenie łuszczyn rzepaku ozimego przez patogeny - indeks porażenia [Ip \%]

Table 5. Infection of pods of winter rapeseed by pathogens - index of infection [Ii \%]

\begin{tabular}{|c|c|c|c|c|c|c|c|c|c|}
\hline \multirow{2}{*}{$\begin{array}{l}\text { Rok } \\
\text { Year }\end{array}$} & \multirow{2}{*}{$\begin{array}{l}\text { Odmiana } \\
\text { Cultivar }\end{array}$} & \multicolumn{4}{|c|}{ Czerń krzyżowych - Alternaria spp. } & \multicolumn{4}{|c|}{ Szara pleśń - B. cinerea } \\
\hline & & $\mathrm{O} *$ & SI & I & $\mathrm{x}$ & $\mathrm{O}$ & SI & I & $\mathrm{x}$ \\
\hline \multirow{3}{*}{2009} & Californium & $5,2 \mathrm{a}$ & $4,8 \mathrm{a}$ & $2,3 \mathrm{c}$ & $4,1 \mathrm{a}$ & $7,3 \mathrm{ab}$ & $7,0 \mathrm{ab}$ & $5,0 \mathrm{ab}$ & $6,4 \mathrm{a}$ \\
\hline & Castille & $4,7 \mathrm{a}$ & $4,0 \mathrm{ab}$ & $2,1 \mathrm{c}$ & $3,6 \mathrm{a}$ & $7,5 \mathrm{a}$ & $7,3 \mathrm{ab}$ & $6,8 \mathrm{ab}$ & $7,2 \mathrm{a}$ \\
\hline & Nelson & $2,8 \mathrm{bc}$ & $2,2 \mathrm{c}$ & $2,2 \mathrm{c}$ & $2,4 \mathrm{~b}$ & $6,8 \mathrm{ab}$ & $4,6 \mathrm{~b}$ & $6,2 \mathrm{ab}$ & $5,9 \mathrm{a}$ \\
\hline \multicolumn{2}{|c|}{ Średnia-Mean } & $4,2 \mathrm{a}$ & $3,7 \mathrm{a}$ & $2,2 \mathrm{~b}$ & & $7,2 \mathrm{a}$ & $6,3 \mathrm{a}$ & $6,0 \mathrm{a}$ & \\
\hline \multirow{3}{*}{2011} & Casoar & $6,7 \mathrm{a}$ & $4,5 \mathrm{bc}$ & $5,5 \mathrm{ab}$ & $5,6 \mathrm{a}$ & $11,7 \mathrm{a}$ & $7,1 \mathrm{~b}$ & $7,2 \mathrm{~b}$ & $8,7 \mathrm{a}$ \\
\hline & Artoga & $5,0 \mathrm{bc}$ & 3,5 cde & $3,0 \mathrm{de}$ & $3,8 \mathrm{~b}$ & $7,5 \mathrm{~b}$ & $8,5 \mathrm{~b}$ & $7,3 \mathrm{~b}$ & $7,8 \mathrm{a}$ \\
\hline & Nelson & $4,8 \mathrm{bc}$ & $3,1 \mathrm{de}$ & $2,0 \mathrm{e}$ & $3,3 \mathrm{~b}$ & $4,8 \mathrm{c}$ & $3,3 \mathrm{c}$ & $3,5 \mathrm{c}$ & $3,9 \mathrm{~b}$ \\
\hline \multicolumn{2}{|c|}{ Średnia - Mean } & $5,5 \mathrm{a}$ & $3,7 \mathrm{~b}$ & $3,5 \mathrm{~b}$ & & $8,0 \mathrm{a}$ & $6,3 \mathrm{~b}$ & $6,0 \mathrm{~b}$ & \\
\hline \multirow{3}{*}{2012} & Californium & $9,3 \mathrm{a}$ & $9,3 \mathrm{a}$ & $6,7 \mathrm{ab}$ & $8,4 \mathrm{a}$ & $9,3 \mathrm{a}$ & $7,3 \mathrm{ab}$ & $6,7 \mathrm{ab}$ & $7,8 \mathrm{a}$ \\
\hline & Castille & $9,3 \mathrm{a}$ & $4,7 \mathrm{ab}$ & $4,7 \mathrm{ab}$ & $6,2 \mathrm{~b}$ & $8,7 \mathrm{a}$ & $6,0 \mathrm{ab}$ & $6,7 \mathrm{ab}$ & $7,1 \mathrm{a}$ \\
\hline & Nelson & $8,7 \mathrm{ab}$ & $8,0 \mathrm{ab}$ & $6,7 \mathrm{ab}$ & $7,8 \mathrm{a}$ & $6,7 \mathrm{ab}$ & $5,3 \mathrm{ab}$ & $2,3 \mathrm{~b}$ & $4,8 \mathrm{~b}$ \\
\hline \multicolumn{2}{|c|}{ Średnia-Mean } & $9,1 \mathrm{a}$ & $7,3 \mathrm{a}$ & $6,0 \mathrm{a}$ & & $8,2 \mathrm{ab}$ & $6,2 \mathrm{ab}$ & $5,2 \mathrm{~b}$ & \\
\hline
\end{tabular}

*technologie - technologies: O - oszczędna - economical; SI - średnio intensywna - medium intensive; I - intensywna - intensive $\mathrm{x}$ - statystyka w obrębie lat - statistics for years

Wartości oznaczone w kolumnach tymi samymi literami nie różnią się istotnie - The values in columns marked with the same letters are not significantly different

Tabela 6. Porażenie łodyg rzepaku ozimego przez patogeny - indeks porażenia [Ip \%]

Table 6. Infection of stems of winter rapeseed by pathogens - index of infection [Ii \%]

\begin{tabular}{|c|c|c|c|c|c|}
\hline \multirow{2}{*}{ Rok - Year } & \multirow{2}{*}{ Odmiana - Cultivar } & \multicolumn{4}{|c|}{ Sucha zgnilizna kapustnych $-P$. lingam } \\
\hline & & $\mathrm{O} *$ & SI & I & $\mathrm{x}$ \\
\hline \multirow{3}{*}{2009} & Californium & $10,8 \mathrm{a}$ & $8,4 \mathrm{ab}$ & $9,9 \mathrm{ab}$ & $9,7 \mathrm{a}$ \\
\hline & Castille & $9,9 a b$ & $9,3 \mathrm{ab}$ & $10,2 \mathrm{ab}$ & $9,8 \mathrm{a}$ \\
\hline & Nelson & $7,2 \mathrm{bc}$ & $4,8 \mathrm{c}$ & $5,4 \mathrm{c}$ & $5,8 \mathrm{~b}$ \\
\hline \multicolumn{2}{|c|}{ Średnia - Mean } & $9,3 \mathrm{a}$ & $7,5 \mathrm{~b}$ & $8,5 \mathrm{ab}$ & \\
\hline \multirow{3}{*}{2011} & Casoar & $21,5 \mathrm{ab}$ & $11,4 \mathrm{~cd}$ & $7,3 \mathrm{~d}$ & $13,4 \mathrm{a}$ \\
\hline & Artoga & $22,4 \mathrm{a}$ & $13,6 \mathrm{c}$ & $10,2 \mathrm{~cd}$ & $15,4 \mathrm{a}$ \\
\hline & Nelson & $12,2 \mathrm{c}$ & $18,2 \mathrm{~b}$ & $9,5 \mathrm{~cd}$ & $13,3 \mathrm{a}$ \\
\hline \multicolumn{2}{|c|}{ Średnia - Mean } & $18,7 \mathrm{a}$ & $14,4 \mathrm{~b}$ & $9,0 \mathrm{c}$ & \\
\hline \multirow{3}{*}{2012} & Californium & $16,3 \mathrm{a}$ & $13,0 \mathrm{abc}$ & $12,0 \mathrm{abc}$ & $13,8 \mathrm{a}$ \\
\hline & Castille & $15,0 \mathrm{ab}$ & $14,7 \mathrm{ab}$ & 8,7 cde & $12,8 \mathrm{a}$ \\
\hline & Nelson & $11,3 \mathrm{bc}$ & $11,0 \mathrm{bcd}$ & $5,0 \mathrm{e}$ & $9,1 \mathrm{~b}$ \\
\hline \multicolumn{2}{|c|}{ Średnia - Mean } & $14,2 \mathrm{a}$ & $12,9 \mathrm{ab}$ & $8,6 \mathrm{c}$ & \\
\hline
\end{tabular}

*technologie - technologies: O - oszczędna - economical; SI - średnio intensywna - medium intensive; I - intensywna - intensive $\mathrm{x}$ - statystyka w obrębie lat - statistics for years

Wartości oznaczone w kolumnach tymi samymi literami nie różnią się istotnie - The values in columns marked with the same letters are not significantly different 
łuszczyn rzepaku, czego nie stwierdzają w przypadku późnej i silnej infekcji łuszczyn. O znaczeniu terminu stosowania środków ochrony roślin na ich skuteczność w ograniczaniu występowania patogenów rodzaju Alternaria dowiadujemy się $\mathrm{z}$ innych badań (Brazauskiene i Petraitiene 2003; Jajor i wsp. 2013).

Porażenie łodyg rzepaku przez sprawców suchej zgnilizny kapustnych wahało się od około $5 \%$ na odmianie Nelson w technologii średnio intensywnej (2009 r.) do $20 \%$ na odmianie Casoar i Artoga w technologii oszczędnej (2011 r.) (tab. 6). Na obniżenie zdrowotności roślin rzepaku w ostatnich dwóch analizowanych terminach miały prawdopodobnie wpływ niekorzystne warunki w czasie ruszania wegetacji, tj. niskie temperatury w marcu i na początku kwietnia, co mogło zwiększyć presję patogena względem osłabionych roślin. Najsilniejsze objawy tej choroby odnotowano na łodygach rzepaku ozimego odmiany Artoga, uprawianego w technologii oszczędnej. Wraz ze wzrostem intensyfikacji uprawy rzepaku ozimego obserwowano zmniejszenie nasilenia występowania objawów powodowanych przez sprawcę suchej zgnilizny na łodygach. Wyjątek stanowił pierwszy rok trwania doświadczenia, w którym najmniejsze porażenie odnotowano na roślinach rzepaku w średnio intensywnej technologii. Na odmianie Nelson zanotowano istotnie słabsze objawy choroby w stosunku do pozostałych odmian (w 2009 i 2012 r.). Sauzet i wsp. (2003) informują o nasilonej infekcji przez $P$. lingam rzepaku w uprawie bezorkowej, podczas gdy Söchting i Verreet (2003) nie stwierdzają zależności występowania choroby od rodzaju uprawy. Dowiedziono, że występowanie choroby ograniczała niższa norma wysiewu i większa rozstawa rzędów (Pusz 2007) oraz ochrona chemiczna stosowana jesienią czy jesienią i wiosną (Jajor i wsp. 2012).

\section{Wnioski / Conclusions}

1. Zaobserwowano mniejsze nasilenie objawów chorobowych na roślinach wraz ze wzrostem intensyfikacji technologii produkcji rzepaku ozimego.

2. Stwierdzono zróżnicowane nasilenie zgnilizny twardzikowej i czerni krzyżowych na łuszczynach rzepaku analizowanych odmian. Najsłabsze objawy pozostałych chorób stwierdzono na odmianie Nelson.

3. Warunki pogodowe w dużym stopniu modyfikowały nasilenie występowania chorób rzepaku ozimego.

\section{Literatura / References}

Banaszkiewicz T., Borkowska K. 2006. Ocena wybranych cech fizykochemicznych oraz zawartości energii metabolicznej nasion rzepaku w aspekcie ich wielkości. Rośliny Oleiste - Oilseed Crops 27: 367-376.

Brazauskiene I., Petraitiene E. 2003. Dynamic of Alternaria blight (Alternaria spp.) spread on spring oilseed rape leaves and siliques and variation of the disease parameters under the effect of prochloraz and tebuconazole in relation application time. J. Plant Prot. Res. 43 (4): 313-323.

Haneklaus S., Bloem E., Schnug E. 2007. Sulfur and plant disease. p. 101-118. In: „Mineral Nutrition and Plant Diseases” (L. Datnoff, E. Elmer, D. Huber, eds). APS Press, St. Paul, MN, 278 pp.

Jahangir M., Kim H.K., Choi Y.H., Verpoorte R. 2009. Health-affecting compounds in Brassicaceae. Compr. Rev. Food Sci. Food Saf. 8 (2): 31-43.

Jajor E., Horoszkiewicz-Janka J., Wickiel G. 2013. Wpływ ochrony przy użyciu fungicydów na ograniczanie występowania grzybów na łuszczynach i nasionach rzepaku. [Influence of fungicide application on limitation of fungi on oilseed rape siliques and seeds]. Prog. Plant Prot./Post. Ochr. Roślin 53 (4): 768-773.

Jajor E., Horoszkiewicz-Janka J., Danielewicz J., Korbas M. 2012. Wpływ zmianowania i fungicydów na ograniczenie występowania chorób rzepaku ozimego. [Influence of crop rotation and fungicides on occurrence limitation of winter oilseed rape diseases]. Prog. Plant Prot./Post. Ochr. Roślin 52 (4): 1005-1010.

Korbas M., Horoszkiewicz-Janka J., Jajor E. 2008. Uproszczone systemy uprawy a występowanie sprawców chorób. [Simplified systems of soil management in relation to the occurrence of disease casual agents]. Prog. Plant Prot./Post. Ochr. Roślin 48 (4): $1431-1438$

Kotecki A., Kozak M., Malarz W. 2005. Wpływ zróżnicowanej technologii uprawy na rozwój i plonowanie odmian rzepaku ozimego. Rośliny Oleiste - Oilseed Crops 26 (1): 111-124.

Kowalska J., Remlein-Starosta D. 2011. Badania nad możliwością niechemicznej ochrony rzepaku ozimego w Polsce. J. Res. Appl. Agr. Engng. 56 (3): 220-223.

Kurowski T.P., Majchrzak B., Jaźwińska E., Wysocka U. 2008. Skuteczność fungicydu zawierającego fluazynam w ochronie rzepaku ozimego przed kiłą kapusty (Plasmodiophora brassicae Woronin). [Effectiveness of a fungicide containing fluazinam for the protection of winter rape against club root (Plasmodiophora brassicae Woronin)]. Prog. Plant Prot./Post. Ochr. Roślin 48 (1): $212-$ 215.

Łacicowa B. 1970. Badanie szczepów Helminthosporium sorokinianum (H. sativum) oraz odporność odmian jęczmienia jarego na ten czynnik chorobotwórczy. Acta Mycol. 6 (2): 184-248.

Mączyńska A., Głazek M., Krzyzińska B. 2007. Nowe możliwości regulacji wzrostu rzepaku ozimego i ochrony przed chorobami przy zastosowaniu preparatu A 14049 (difenokonazol i pachlobutrazol). [New possibilites of growth regulation and protection against fungal diseases of winter oilseed rape using the preparation A 14049 (difenoconazole and paclobutrazol)]. Prog. Plant Prot./Post. Ochr. Roślin 47 (2): 198-202.

Mączyńska A., Krzyzińska B., Pietryga J. 2002. Efektywność zwalczania chorób łuszczyn rzepaku ozimego przy wczesnej i późnej infekcji. Rośliny Oleiste - Oilseed Crops 23 (1): 409-416.

Pusz W. 2007. Wpływ obsady roślin w łanie na zdrowotność rzepaku ozimego. Zesz. Nauk. UP Wrocław, Rolnictwo 553: 83-101. 
Rathke G.W., Behrens T., Diepenbrock W. 2006. Integrated nitrogen management strategies to improve seed yield, oil content and nitrogen efficiency of winter oilseed rape (Brassica napus L.): A review. Agr. Ecosyst. Environ. 117: 80-108.

Rimmer S.R., Shattuck V.I., Buchwaldt L. 2007. Compendium of Brassica Diseases. APS Press, St. Paul, MN, 117 pp.

Sauzet G., Reau R., Palleau J. 2003. Evaluation of oilseed rape crop managements with minimum tillage. p. 863-864. In: Proc. 11th International Rapeseed Congress 3. Denmark, Copenhagen, 6-10 July 2003, 1050 pp.

Söchting H.P., Verreet J.A. 2003. Effects of different cultivation systems (soil management, nitrogen fertilization) on the epidemiological behaviour of fungal diseases in oilseed rape (Brassica napus L. var. napus). J. Plant Dis. Prot. 111 (1): 1-29.

Starzycka E., Starzycki M. 1994. Badania podatności pędów i liści rzepaku ozimego na porażenie przez Sclerotinia sclerotiorum. Rośliny Oleiste - Oilseed Crops 15: 83-85.

Wielebski F. 2012. Reakcja rzepaku ozimego na nawożenie siarką w zależności od poziomu zaopatrzenia roślin w azot. Rośliny Oleiste - Oilseed Crops 33: 245-272 .

Wittkop B., Snowdon R., Friedt J. 2009. Status and perspectives of breeding for enhanced yield and quality of oilseed crop for Europe. Euphytica 170: 131-140.

Wójtowicz M., Jajor E. 2010. Wpływ wybranych czynników technologii produkcji na plony rzepaku ozimego. [Effect of some production technology factors on the yield of winter oilseed rape]. Prog. Plant Prot./Post. Ochr. Roślin 50 (2): 565-569.

Zhao F.J., McGrath S.P., Blake-Kalff M.M.A., Link A., Tucker M. 2002. Crop responses to sulphur fertilisation in Europe. Proc. Fertiliser Society 504: 1-7. 